TEME, г. XLIV, бр. 1, јануар - март 2020, стр. 49-64

\begin{tabular}{lr}
\hline \hline Оригинални научни рад & https://doi.org/10.22190/TEME191202008V \\
Примљено: 2. 12.2019. & UDK 347.426:347.5
\end{tabular}

Ревидирана верзија: 21. 1. 2020.

Одобрено за штампу: 20. 2. 2020.

\title{
LEGALLY RELEVANT DAMAGE ${ }^{a}$
}

\section{Ivana Simonović}

University of Niš, Faculty of Law, Niš, Serbia ivana@prafak.ni.ac.rs

\begin{abstract}
The author analyzes legally relevant damage - a concept used by the Study Group on European Civil Code in order to define those losses for which a legal redress is given under the tort law. There are eleven particular instances of legally relevant damage caused either to one's personality, rights or property. What is also important are the infringements of other rights and interests, but they need to satisfy additional criteria in order to be recognized as legally relevant damage. Only such rights that enjoy protection against everyone are protected, therefore, anyone can infringe them. Interests are also protected if they satisfy the requirements to be worthy of legal protection.
\end{abstract}

Key words: legally relevant damage, loss, tort liability.

\section{ПРАВНО ЗНАЧАЈНА ШТЕТА}

\section{Апстракт}

У раду је анализована правно значајна штета, појам којим је Студијска група за Европски грађански законик означила губитке надокнадиве по правилима одштетног права. Осим једанаест посебно уређених врста правно значајне штете, дати су и критеријуми на основу којих ће постојање овакве штете бити утврђивано у случајевима необухваћеним њеним посебним врстама. Важно је да буде повређено право које делује према свима или интерес достојан правне заштите.

Кључне речи: правно значајна штета, губитак, деликтна одговорност.

\footnotetext{
${ }^{a}$ This paper is the result of research conducted in the framework of the project Harmonization of the Law of the Republic of Serbia with the EU Law, financed by the Faculty of Law University of Niš.
} 


\section{INTRODUCTION}

Not every loss which one suffers and is prone to call damage actually is damage in a legal sense. In the eyes of the law, damage is only such a loss for which legal remedy is provided, namely a right of the injured person to ask reparation from the person who caused the loss or other responsible person.

It is not an easy task to give one general definition of damage that could encompass all of its manifestations, for there are many differences between them. Like most of the European laws, Serbian legislator does not define damage; instead two instances of damage are regulated material and non-material damage - and three manifestations of the latter: physical pain, mental pain and suffering and fear.

The definition of damage is left to the law theory where it is said that damage is the infringement of material or non-material (personal) subjective rights or legally protected interests belonging to another person, and this infringement should be removed according to the rules of the tort law (Pop Georgiev, 1980). The law recognizes only such reductions in assets, or prevention from its reasonably expected increase, which is caused by someone else's prohibited behavior and is to be repaired by that responsible person (Radišić, 2008, pp. 197).

These definitions teach us that the legal notion of damage focuses on several points. First, damage is such detrimental impact which a person suffers against his/her will; also, this detriment is caused to the person's legally protected rights and interests; and, lastly, it is that detriment that is to be removed by a person who caused it or is in another way responsible for it. In case that the injured person must deal with his/her loss by himself/herself, and not be able to ask reparation from other else, then we are only faced with economic loss, but not with legally relevant damage.

Judging by the projects for the unification or codification of the European private law, we may say that legally relevant damage, which is one of the requisites for the imposition of delictual liability, arises as an important concept in modern tort law. Instead of the enumeration of the legally protected rights and interests, these projects find it more important to determine the requisites under which the loss of one person (either material or non-material) can be attributed to another person who is then responsible to remove it by way of reparation in kind or money. Provided that these conditions are met, then we are in the presence of legally relevant damage, for which the law provides adequate remedy. This kind of approach we find in the project prepared by the Study Group on the European Civil Code, under the auspices of professor Christian von Bar, published in 2009, under the title "Principles of European Law, NonContractual Liabilaty Arising out of Damage Caused to Another" (from here after: PEL Liab. Dam.). Worth mentioning are also the project of the European Group for Tort Law, run by professor Helmut Koziol (Principles 
of European Tort Law, PETL, art. 1: 101, 2: 102 and 3: 201), but also the work of several commissions for the reform of the French obligation law and the Austrian tort law. ${ }^{1}$

In this paper we focus our attention on the concept of legally relevant damage as defined in the Principles of the European Law, the Non-Contractual Liability Arising out of Damage Caused to Another. Before that, we turn our attention to the purpose of tort law and to the notion of damage from a comparative perspective.

\section{THE PURPOSE OF TORT LAW AND THE REMEDY FOR THE DAMAGE CAUSED}

In all European legal systems there are rules on the bases of which it is decided whether a person who has suffered damage can demand reparation from another or, in case of impending damage, that preventive measure be taken. The law containing these rules is called tort law (law of delict) which establishes the criteria which - if satisfied - guarantee the right of the injured person to be put in the position in which he/she would be, had the detriment not occurred. In order to serve this purpose, the tort law can rely on a general principle that anyone who causes damage to another is obliged to make reparation (neminem laedere principle). Another method is to establish a list of protected rights and legal interests for which a remedy in tort law is provided. The closer inspection of European laws shows that both approaches are present, but neither of them gives an exhaustive list of all the protected rights and interests, for it is almost impossible to create such a closed catalogue. Laws which rely on some kind of enumeration (such as the German and Austrian laws) are also open to protection of other rights and interests, provided that prescribed requirements of tort liability are met.

Not every loss constitutes damage. All legal systems distinguish between loss and damage and do not identify one with the other. Some losses are recoverable under the tort law, for they are conceived as damage, other must be borne by a person who suffered the loss. "The law of delict can only operate as an effective, sensible and fair system of compensation if excessive liability is avoided" (Von Bar, 2000, p. 4). We would also like to add that setting borders between loss and damage is necessary to prevent spreading liability on the remote consequences of one's conduct, therefore, they must be exempt from responsibility.

In order to accomplish a fair balance of interests involved, the law needs to establish certain criteria for moving the loss, which represents

\footnotetext{
${ }^{1}$ For further reading about other here mentioned projects, see: Ranieri, 2008, pp.
} 1457-1464, 1533-1538 
damage, from the sphere of the person who suffered it into the sphere of a person who is obliged to bear it eventually, for the loss can be attributed to his/her conduct or omission. Defining damage and setting requirements of tort liability are at the core of tort law.

„The purpose of the law of torts consists predominantly in protecting human and basic rights at the level of private law, that is to say horizontally between citizens inter se, with the legal remedies made mutual available.” (Von Bar, 2009, pp. 229)

"Liability in tort should protect property of a person from being unlawfully damaged by others, as well as her non-material (personality) rights." (Klarić \& Vedriš, 2009, pp. 583)

Damage is the detrimental infringement of the legally protected rights and interests held by one person, which the person responsible for the damage is obliged to repair. Seen from the perspective of the requirements for tort liability, together with causation and accountability, damage is a necessary and constant ${ }^{2}$ constituent of every liability regardless of the ground of accountability (fault, created risk or equity).

In most of the European legal systems the mere violation of the protected right does not represent damage. A further loss is required because tort liability is imposed for the consequences of one's (unlawful) behavior, not for behavior itself. An injured person must prove his/her loss, usually by comparing his/her current material position with a hypothetical one, one which would have existed had the harmful event not occurred, therefore establishing obligation to make reparation (the so-called Differenztheorie). The decreased value of the infringed person's property represents the legally relevant damage and loss that can be repaired (provided that all other requirements of tort liability are met). Non-material damage which cannot be assessed in economic terms is also recoverable for the purpose of the satisfaction of the injured person.

\section{THE CONCEPT OF DAMAGE FROM THE COMPARATIVE PERSPECTIVE}

The concept of damage is seldom defined in civil codes. Apart from a few exceptions, we can name the Austrian Civil Code and the Serbian Act on Obligation Relationships which, in fact, determine the

\footnotetext{
${ }^{2}$ Occasional requirements are the fault and wrongfulness of behavior which caused the damage. Fault does not figure in cases of strict liability (damage caused by dangerous thing or dangerous activity), where a person is responsible for the created risk, independently of any fault on his/her side. Equitable liability is also based on the non-fault principle. (See: Radišić, 2008, p. 196. Also: Klarić \& Vedriš, 2009, p. 584 and Crnić, 2008, p. 4, who divides liability requirements into general and special; according to this division, damage is common to all types of liability, therefore, it is a general requisite.)
} 
instances of damage. The Austrian Civil Code (Allgemeines Bürgerliches Gesetzbuch - ABGB, 1811, § 1293) states that damage is any harm caused to a person's property, rights or person). According to art. 155 of the Serbian Act on Obligation Relationships (Закон о облигационим односима, 1978) damage is the reduction in the value of one's property (plain damage) and the prevention of reasonably expected increase of its value (lost benefit), also the infliction of physical pain, mental pain and suffering and fear (non-material damage). The law makes both material and non-material damage recoverable (for the latter, under the rules set in art. 200 of the Serbian Act on Obligation Relationships) and both of them are the result of the interference with another person's subjective rights and legally protected interests.

The history of law teaches us that the first delictual claims were precisely determined: there were specific torts which protected a person from the precisely determined type of harm. This is best shown on the example of the Roman law. Roman jurists recognized particular torts and had never came to a general principle that the person who causes damage to another has to give adequate reparation.

The most important torts - iniuria, furtum and an action under lex Aqulia - had very narrow circle of protected rights. The action for iniuria could be given for different kinds of offensive behaviors which injure bodily integrity, freedom and the life of another; an action for furtum protected property of the claimant (at first from theft, later from every unauthorized interference with property, such as the unauthorized use of thing belonging to other) (Zweigert \& Kötz, 1996). There were two basic requirements for an action under lex Aquilia (or the so-called Aquilian liability): the defendant had to be at fault (i.e. causing damage intentionally or negligently), and that the claimant suffered certain types of harms (Gordley, 2006, p. 160). For example, one who kills a slave or an animal had to pay a fine of a certain amount (Stojanović, 1982, pp. 1180).

The casuistic method of the Roman law was an obstacle for establishing one general rule that anyone who causes damage to another is obliged to repair it. For such a clause one had to wait until $19^{\text {th }}$ century and the first civil law codifications written under the influence of the natural law. Article 1382 of the French Civil Code (Code Civil, 1804) is known as one of the first rules that provide the general duty of reparation of the damage caused, faute (through fault, either acting intentionally or negligently). The French courts had the responsible task of establishing additional requirements for tort liability. Soon after the French Code entered into force the meaning of damage (dommage) had to be defined, for nothing in this Code explains this expression. The French courts adopted an approach that both material as well as non-material damage (dommage moral) are recoverable, provided that all other requirements are met (See: Von Bar, 2009, pp. 315-316). 
The fathers of the German Civil Code took a different approach. Instead of a general clause, they provided three separate paragraphs which determine the domain and common requirements of tort liability. Paragraph 823 of the German Civil Code (Deutsches Bürgerliches Gesetzbuch BGB) draws up a list of the protected rights and interests. The first section of this paragraph provides that a person who intentionally or negligently, unlawfully (widerrechtlich), injures the life, the health, the freedom, property or similar right (sonstiges Recht) of another has a duty to compensate for the inflicted damage. Under the expression, similar right protection was guaranteed for other rights, not included in the list, provided that they are absolute rights, protected against everyone, therefore anyone can infringe them (Zweigert \& Kötz: 1996; Teichmann, Jauernig, 2007, pp. 1112). Alongside these enumerated rights, according to para 823 section (2) of the BGB, liability can be imposed for the breach of statutory duty whose purpose is the protection of a person suffering damage from that damage. The third pillar of tort liability in the German law is paragraph 826 of the BGB which makes recoverable the damage caused by an act contrary to good faith and fair dealing (verstoß gegen guten Sitten). This rule protects both the material and non-material interests from intentionally or negligently caused damage. For liability it is enough that the injured person proves that the injuring person could have reasonably known that damage was possible and yet did nothing to prevent it (Zweigert \& Kötz, 1996).

The dominant feature of the French tort law is that it is developed in court practice. Yet, one cannot dispute the creative role of the German courts in making additional rules on tort liability. Soon after the BGB came into force, it became evident that paragraphs mentioned earlier are insufficient for the protection of those rights and legal interests which they do not mention, but are worthy of protection. The Code explicitly protects the most important personal assets such as life, freedom and bodily integrity (name, picture and copyright are protected by separate provision of the Code), but the entire personality is not protected. The German Federal court made it possible with its opinion from 1954 that general right to personality is that similar right mentioned in $\S 823$ subpar. 1 of the BGB. The same applies to the right to freely exercise business activity (Zweigert \& Kötz, 1996).

The Roman law tradition is usually associated with civil law legal system. Yet, when it comes to the tort law, on the examples of French and partially German law, we see a divergence; the casuistic method is not a feature of laws which are part of this system. The English tort law, on the other hand, developed similarly to the Roman law actions for inflicted harm - particular types of actions prohibit distinct types of wrongs and 
protect one specific right. ${ }^{3}$ There are roughly around 70 to 75 torts, out of which trespass, negligence (which is the most important), breach of statutory duty, nuisance and defamation are the most frequent in court practice (Von Bar, 2009, pp. 230).

\section{THE VIOLATION OF PERSONALITY RIGHTS AS DAMAGE}

The concept of material damage in Croatian obligation law is similar to its Serbian counterpart due to their shared legal tradition. The point of departure is the definition of non-material damage; the Croatian Act on Obligation Relationships from 2005 (Zakon o obveznim odnosima Republike Hrvatske, čl. 1046) opted for the objective concept, according to which a mere infringement of personality rights constitutes nonmaterial damage. Nonetheless, remedy, specifically, the right to equitable compensation, is only given under additional requirements set in art. 1099-1106. In case of a dispute, the court will decide whether monetary compensation is justified by taking into account the seriousness of injury and the circumstances of the case (Zakon o obveznim odnosima, čl. 1100, st. 2). ${ }^{4}$ This new concept, which is in line with modern theory on nonmaterial damage, was criticized in law theory. It was said that it does not reflect the true nature of tort law, one concerned with the reparation of the consequences the injured person suffers. Damages should be given for the consequences which, in case of non-material damage, are various types of physical and/or mental pain and suffering (Crnić, 2008, pp. 557-558).

The objective concept of non-material damage points out the importance of protected rights and interests allowing their mere infringements to be enough for legally relevant damage and compensation. These rights are personality rights which enjoy special protection. Not only that they are protected by constitutional and criminal law rules, but civil law protection is also provided with the rule that violation of personality rights is damage per se and gives right to remedy. This remedy need not to be monetary compensation, for circumstances of the case may indicate that some other remedy is better suited. For example, the violation of one's honor

\footnotetext{
${ }^{3}$ Until $19^{\text {th }}$ century, the English law was organized by writs where classifications and definitions of different species of injuries had to be based on the old procedural distinction between forms of action. (Salmond, Torts, 182, according to Gordley, 2006, p. 181, footnote 151)

${ }^{4}$ The seriousness of an injury will be assessed by the court on the basis of intensity and length of physical and mental pain and fear. These parameters are „obstacles to lucrative aspirations and commercialization of non-material damage" (Crnić, 2008, 644). The court will also appraise the purpose of monetary compensation and will not allow that it is used for purposes not in line with its nature and function (art. 1100 of the Croatian Act on Obligation Relationships).
} 
and reputation can be better sanctioned with an apology for slander or by the withdrawal of the newspaper containing the defamatory article.

The concept of non-material damage is familiar to most of the European legal systems. There are laws, such as the Italian law, which recognize another type of damage called biological damage (danno biologico) (Von Bar, 2000, pp. 24). This damage arises from the violation of the right to psycho-physical integrity protected by the constitution and can be repaired independently of any material or non-material damage (danno patrimoniale and danno morale, Codice civile, 1942, art. 2043 and art. 2059).

The concept of biological damage is the result of the work of Italian courts which redefined the general concept of damage. It was no longer only the difference in the economic position of the victim before and after the damaging event. Rather, the violation of the person's body or health constitutes the danno evento, to be compensated even when the plaintiff can claim damages for neither pain nor suffering under art. 2059 of the Italian Code, nor pecuniary loss under art. 2043 (Von Bar, 2000, pp. 24). The remedy for danno evento (event-related damage) is a compensation which is quite autonomous from other remedies that might be given for further losses the claimant suffers. This way, biological damage has become the third type of damage in Italian law, next to material and nonmaterial damage. All three types of damages are independent from each other, and the compensation of one type does not preclude the compensation for the other two. It seems that the concept of biological damage has become established in court practice and is not disputed.

"The current question in Italy is thus not whether to retreat from the current position, but whether the concept of danno evento can justifiably be restricted to personal injuries alone." (Von Bar, 2000, pp. 27). ${ }^{5}$

\section{THE CONCEPT OF LEGALLY RELEVANT DAMAGE}

The Study Group on the European Civil Code decided to use the concept of legally relevant damage as one of general requirements for tort liability established in article 1:101 of PEL Liab. Dam. which serves as the basic rule. It states: A person who suffers legally relevant damage has a right to reparation from a person who caused the damage intentionally or negligently or is otherwise accountable for the causation of the damage (Article 1: 101: Basic rule). Therefore, the prerequisites for tort liability

\footnotetext{
${ }^{5}$ It seems that courts in Portugal are also ready to acknowledge biological damage as a third form of damage. It is viewed as a moral damage (compensable independently of compensation for pain and suffering) in case of severe physical alteration of an individual or his way of life resulting from loss of health, freedom, free will or privacy. (Von Bar, 2009, p. 27)
} 
are: legally relevant damage, grounds of accountability ${ }^{6}$, causation and absence of defenses ${ }^{7}$.

Rules of the Chapter 2 of PEL Liab. Dam. explain what is to be considered as legally relevant damage. There are eleven particular instances of damage which are preceded by the rule containing the criteria for establishing tort liability for those infringements which are not specifically mentioned in the following articles.

In order to ascertain whether a person has suffered a legally relevant damage one must start with the rules which regulate the particular instances of the legally relevant damage (PEL Liab. Dam. Section 2, art. 2: 201-2: 211). The Rule from the beginning of the fifth Chapter (art. 2:101 Meaning of legally relevant damage) applies as a subsidiary - if the infringed right or interest is not categorized among particular forms of damage. The drafters decided for this order of rules to avoid the wrong impression that the list of legally relevant damage closes with those eleven particular forms of damage and that the protection of other rights and interests is not possible (Von Bar, 2009, p. 301). The list is open for new forms of damage under the criteria set up in art. 2:101 of PEL Liab. Dam. which will be decided by the court. Article 2:101 of PEL Liab. Dam which explains the meaning of legally relevant damage is a blanket rule and is to be determined in every day court practice.

\section{PARTICULAR INSTANCES OF LEGALLY RELEVANT DAMAGE}

Closer inspection of articles 2: 201-2: 211 of PEL Liab. Dam. shows that particular instances of damage are typical infringements of rights and interests which are sanctioned under tort liability in most European laws. First, there is damage as a result of the infringement of personality rights. These are: damage to the person (death, personal injury and consequential loss, infringement of dignity, liberty and privacy); damage resulting from the communication of incorrect information about another and loss upon breach of confidence. These instances of damage are followed by provisions on damage to the property and proprietary interests (loss upon infringement of property and lawful possession), damage as a consequence of reliance on incorrect advice or information, loss upon unlawful impairment of business and pure ecological damage.

\footnotetext{
${ }^{6}$ Grounds of accountability are: intention and negligence, accountability for damage caused by employees and representatives (vicarious accountability), accountability for damage caused by defective products, by dangerous substances or emissions (see: Chapter 3 of PEL Liab. Dam.).

${ }^{7}$ Defenses can relieve responsible person of liability for damage ( see: Chapter 5 of PEL Liab. Dam.).
} 
A person can be held accountable for the causation of damage mentioned in the previous section if he/she acted either with the intention or he/she was negligent, but also independently of any fault on his/her side. We point out this fact because there are few instances of damage which can be present only if there is intentional conduct. These cases are fraudulent misrepresentation (deceit) and inducement of non-performance of obligation.

\section{THE MEANING OF LEGALLY RELEVANT DAMAGE}

As already mentioned, the concept of legally relevant damage is set upon three pillars. The first pillar encompasses the eleven particular instances of damage, regulated in detail by special provisions, which by no means complete the list of rights and interests protected by the law of tort. ${ }^{8}$ Important are also the infringements of other rights and interests, but they need to satisfy additional criteria in order to be recognized as legally relevant damage. Provisions regulating these criteria are the second and the third pillar of the concept of legally relevant damage as seen by the drafters of the Principles of European Law.

The article 2: 101: Meaning of legally relevant damage reads as follows:

(1) Loss, whether economic or non-economic, or injury is legally relevant damage only if:

(a) one of the following rules of this Chapter so provides;

(b) the loss or injury results from a violation of a right otherwise conferred by the law; or

(c) the loss or injury results from violation of an interest worthy of legal protection.

(2) In any case covered only by sub-paragraphs (b) or (c) of paragraph

(1) loss or injury constitutes legally relevant damage only if it would be fair and reasonable for there to be a right to reparation or prevention, as the case may be, under Articles 1: 101 (Basic rule) or 1: 102 (Prevention).

(3) In considering whether it would be fair and reasonable for there to be a right to reparation or prevention regard is to be had to the ground of accountability, to the nature and proximity of the damage or impending damage, to the reasonable expectations of the person who suffers or would suffer the damage, and to the consideration of public policy.

\footnotetext{
8 "The second chapter does not seek to draw up a list of abstract interests protected by the law of tort; rather it seeks to clarify within the specific context the concept of "legally relevant damage" within the meaning of basic norm - (...) damage which will be recognized for the purpose $\mathrm{s}$ of founding liability in tort, given all the other ingredients of claim." (Von Bar, 2009, p. 299)
} 
(4) In this Book:

(a) economic loss includes the loss of income or profit, burdens incurred and reduction in the value of the property

(b) non-economic loss includes pain and suffering and impairment of the quality of life.

The analysis of these provision first shows that there are two manifestations of damage - loss and injury per se; then, that they can result from the violation of one's subjective right or legally protected interest. Protected are only such rights which enjoy protection against everyone, therefore anyone can infringe them. In the civil law legal system these rights are called absolute rights and include property rights, personality rights, trademarks rights and copyright. Their exclusive nature gives them a special status, among other things, noticeable in privileged protection in tort law. It need not be a right within the private law, and the right to vote, or a right not to be discriminated against are also included (see: Von Bar, 2009, p. 307). What matters is that these rights have the erga omnes effect, therefore contractual rights are excluded ${ }^{9}$.

Infringement of legally protected interests can also constitute legally relevant damage. The drafters used the expression 'an interest worthy of legal protection ${ }^{10}$ (art. 2: 101 para 1 subpar b) and, whether there is such, the court will decide using criteria set in paragraphs 2) and 3). Before we examine these criteria, we will first explore loss and injury as two manifestations of legally relevant damage.

\section{LOSS AND INJURY AS DAMAGE}

The drafters followed the dominant European legal tradition by making both economic (material) as well non-economic (non-material) loss compensable (art. 2: 101 para 1 of PEL Liab. Dam.). In order to establish whether there is an economic loss, one must compare the current material position of the injured person with his/her material position prior to the event which caused the damage; if there is a reduction in the property value (negative difference between the compared positions), the injured party has a right to reparation, either in kind or in money (the last

\footnotetext{
${ }^{9}$ But, an inducement to breach a contract is a special instance of legally relevant damage (see art. 2: 211 of PEL Liab. Dam.) for a third person has intentionally caused one contracting party not to perform his/her obligation.

${ }^{10}$ This is a linguistic innovation which does not feature in any of the Civil Codes or Damage Liability Acts, but it is known in jurisprudence of many countries. In Serbian law often it is required from a claimant to prove his legitimate interest in order to address the court and ask for legal protection (according to art. 188 of the Civil Procedure Act, a claim to establish an existence or non-existence of a right or legal relationship can only be brought in special situations provided that the claimant has legal interest).
} 
called compensation). The aim of the reparation is to reinstate the injured person in the position that he/she would have been in had the legally relevant damage not occurred (art. 6: 101 para 1 of PEL Liab. Dam.). Unlike the Serbian obligation law, where reparation in kind has priority over monetary compensation (see art. 185 para 2 and 3 of Act on Obligation Relationships), PEL follows the common law principle and establishes reparation in money as a general rule. The amount of the sum will be assessed according to the economic rules of the market for the harmed interest has a market value. In art. 2: 101 para 4 typical forms of economic losses are given. They include the loss of income or profit, the burdens incurred and reduction in the value of the property.

There are situations where reparation in kind is a better remedy than monetary compensation. The owner of a stolen thing has a right to vindicate it for only such a reparation reinstates him in the position held prior to the damage suffered. Yet, the main field of reparation in kind is the infringement of personality rights. This leads us to the second manifestation of reparable loss, namely non-economic loss, which includes pain and suffering and the impairment of the quality of life (art. 2: 101 para 4 subpara b). ${ }^{11}$ These losses cannot be assessed according to the rules of the market for the infringed rights and interests have no market value. The satisfaction of the injured person is the aim of the remedy, which can be achieved by reparation in kind, as well as by payment of money. For example, the injuring person is obliged to retract a false statement, the court orders that judicial decision is to be published in the media (at the expense of the injuring person). If monetary compensation is a remedy, then the injured person will be given the amount of money assessed by the judicial decision. This is by no means an equivalent of the harmed right, but rather an equitable sum which can alleviate the pain and suffering of the injured person. $^{12}$

At the beginning of our discussion it was said that the tort law deals with the consequences of wrongdoing, meaning that in order to establish liability in tort there has to be some detrimental effect on the person's patrimonial or personality rights or protected interests. "Incurring loss is a generally prerequisite for the existence of legal damage" (Von Bar, 2009, P. 320). ${ }^{13}$

\footnotetext{
11 The list is not conclusive therefore one must address the national law in order to establish which types of non-economic damage are recoverable. In the Serbian law there are three types of legally recognized manifestations of such damage: physical pain and suffering, mental pain and suffering and fear (Zakon o obligacionim odnosima, čl. 200, st. 1).

${ }^{12}$ See also art. 200 para 2 of Serbian Act on Obligation Relationships.

${ }^{13}$ Otherwise, tort law will lose its dominantly reparatory function and gain elements of punishment and deterrence, which are the goals of criminal law sanctions.
} 
Yet, there are legal systems where the injury alone (per se) constitutes legally relevant damage. We have already mentioned the Italian concept of danno biologico, which is a good example of one such damage. According to the Italian court practice, the violation of a person's psycho-physical integrity and health (which enjoy special constitutional protection) is not only an event that causes further damage, but an event which per se justifies the obligation to make reparation to the injured party. Therefore, no special proof of actual loss (being economic or non-economic) is required for tort liability.

We can also add the Spanish rule that an infringement of constitutionally protected personality rights, above all bodily integrity, honor, one's own name or image and privacy, are actionable per se. In France, the breach of the prescribed standard of conduct, such as a duty to fair and loyal market competition, presumes the presence of damage if faute commerciale is established (for further reading see: Von Bar, 2009, P. 320-323).

\section{THE CRITERIA FOR ESTABLISHING LEGALLY RELEVANT $D A M A G E$}

Article 2: 101 of PEL Liab. Dam. applies to those rights and legally protected interests which are not regulated by special provisions of the Draft, and it must be further developed in court practice. The Court dealing with the case is equipped with the criteria set in paragraphs (2) and (3) of the said article, which will help him to establish the presence of legally relevant damage. According to paragraph (2) a claimant will be granted a remedy only if it is fair and reasonable to do so, otherwise the infringement of a right or interest does not constitute legally relevant damage. Fairness and reasonable are decided upon: the ground of accountability, the nature and proximity of the damage or impending damage, to the reasonable expectations of the injured person and to the considerations of public policy (paragraph (3)). The assessment of public policy may show that there are better and more suitable legal means to deal with the infringement than those given in tort law. For example, non-performance of an obligation only seldom constitutes non-contractual liability (if it is induced by a third person) for contract law has its own ways of dealing with the breach of contract and has priority over tort law regime.

\section{CONCLUSION}

The law of tort deals with the detrimental consequences which arise out of damage caused to another by prescribing rules which, if satisfied, give an injured person the right to reparation of that damage. The concept of damage is familiar to most European legal systems, but it is rarely defined in their civil codes. Law theory says that damage is a loss a person suffers against his/her will which is caused to his/her rights 
or legally protected interests and is to be removed by a person who caused the loss or is in another way responsible for it. The Study Group on European Civil Code uses the expression legally relevant damage to denote what is to be classified as damage for the purpose of tort law. Although the expression is new it also focuses on these important features of one's loss for which a legal redress is provided under the tort law; the prefix "legally relevant" delineates damage in the legal sense from those detriments which one individual perceives to be damage, but are actually not. There are eleven particular instances of legally relevant damage and one general rule containing the criteria for establishing tort liability for those infringements which are not specially addressed. These criteria are placed in the judge's hands to ascertain the presence of damage and are to be used subsidiary. The judge must establish the infringement of right or interest worthy of legal protection and that circumstances of the case show that it is fair and reasonable to grant a remedy, because if not, the infringement does not constitute legally relevant damage.

At the end of this analysis, we would also like to point out that not every legally relevant damage is reparable. Chapter 6 of the PEL Liab. Dam. makes remedies for the damage sustained depending on the aim of tort liability. The general aim is the restoration into the previous state of affairs (restitutio in integrum), which is to be achieved by way of reparation, compensation (monetary reparation) and prevention. In cases where only preventative legal protection can be given, it is justified to say that although legally relevant damage is present, it does not also constitute a reparable damage. Then a claim for compensation for example of pain and suffering may be dismissed by the court on the basis that it would not be fair and reasonable for there to be a right to reparation.

\section{REFERENCES}

Allgemeines Bürgerliches Gesetzbuch - ABGB, 1811.

Code Civil des Français, 1804.

Codice civile decreto, 1942.

Deutsches Bürgerliches Gesetzbuch, 1896.

Crnić, I. (2008). Odštetno pravo [Law of Tort]. Zagreb: Zgombić \& Partneri.

Gordley, J. (2006). Foundations of Private Law. Oxford: University Press.

Klarić, P., Vedriš,M. (2009). Građansko pravo [Civil Law]. Zagreb: Narodne novine.

Pop Georgiev, D. (1980). Šteta (Damage). U S. Perović i D. Stojanović (Red.), Komentar Zakona o obligacionim odnosima [Comments on Act on Obligation Relationships] (str. 489). Kragujevac: Pravni fakultet i Gorji Milanovac: Kulturni centar.

Radišić, J. (2008). Obligaciono pravo [Obligation law]. Beograd: Nomos.

Ranieri, F. (2008). Europäisches Obligationenrecht,. Wien, New York: Springer-Verlag.

Stojanović, D. (1992). Istorijski razvoj i ciljevi građanskopravne odgovornosti za prouzrokovanu štetu (Hystorical development and functions of civil law liability for damage). Pravni život - Šteta i njena naknada (Legal Life - Damage and Reparation), 9-10, 1179-1190. 
Teichmann, A. (2007). Schadensersatzpflicht In O. Jauernig (Ed.) Jauernig BGB Bürgerliches Gesetzbuch Kommentar (p. 1112). München: Verlag C. H. Beck.

Von Bar, C. (2009). Principles of European Law, Non-Contractual Liability Arising out of Damage Caused to Another. Oxford: Oxford University Press.

Von Bar, C. (2000). The Common Core of European Law of Torts, Vol. Two. Oxford: Clarendon Press.

Закон о облигационим односима, Службени лист СФРЈ. Бр. 29 (1978), 39 (1985), 45 (1989) и 57 (1989), Службени лист СРЈ. Бр. 31 (1993).

Zakon o obveznim odnosima Republike Hrvatske, Narodne novine. Br. 35 (2005) i br. 41 (2008).

Zweigert, K.; Kötz, H. (1996). Einführung in die Rechtsvergleichung auf dem Gebiete des Privatrechts, Bd. II: Institutionen, Tübingen: J. C. B. Mohr (Paul Siebeck).

\title{
ПРАВНО ЗНАЧАЈНА ШТЕТА
}

\author{
Ивана Симоновић \\ Универзитет у Нишу, Правни факултет, Ниш, Србија
}

\section{Резиме}

Није сваки губитак штета. Сви правни системи разликују појмове губитка (оштећења) и штете и не поистовећују их. Неки су губици надокнадиви по правилима одштетног права, јер се сматрају штетом, друге мора да поднесе са̣̂м оштећени. Разграничавањем губитака од штете, те приписивањем правне одговорности само за ово друго - одштетно право (и читав правни систем) - чува само себе од урушавања. Тиме се и спречава ширење одговорности за последице сувише удаљене од радње на коју су се надовезале.

Студијска група за Европски грађански законик појмом правно значајна штета одредила је један од општих услова одштетне одговорности. У сазнавању овог појма треба поћи од издвојених и појединачно уређених облика штете, а општу и уводну одредбу применити супсидијарно - уколико повређено субјективно право или заштићени интерес не спада ни у један од посебних облика штете. Оваквим распоредом правила треба избећи погрешан утисак да се листа затвара са ових једанаест врста штета, без могућности заштите и других правних добара. На листу се могу додавати и друге врсте штета, и то на основу критеријума из члана 2: 101, чије ће постојање утврђивати суд у сваком конкретном случају. Норма о правно значајној штети из члана 2: 101 Нацрта заправо је бланкетно правило, које тек треба операционализовати у судској пракси.

Уколико погледамо одредбе Нацрта у којима су уређене посебне врсте штета, закључићемо да се ради о типичним повредама права и интереса, у већини европских права санкционисане одштетном одговорношћу. Првих неколико врста штета настаје повредом личних права. Реч је о штетама због смрти или повреде психофизичког интегритета друге особе, због повреде части и угледа или права на приватност, изношења или проношења неистинитих информација о другом и због повреде односа поверења. Следе штета проузрокована повредом стварних права и интереса, штета због основаног поуздања у савет или информацију за које у тренутку саопштавања оштећени није знао да су нетачни, штета причињена нелојалном конкуренцијом и неколико врста еколошких штета. 
Мимо ових, посебно издвојених, права и интереса, одштетном одговорношћу заштићена су и друга права и интереси (било уређена нормом грађанског права или нормом јавног права), но само по процени судије и уз испуњење додатних услова. Најпре, потребно је да се ради о праву апсолутног дејства - таквом које делује према свима, па је и према свима заштићено - или о правном интересу достојном правне заштите, затим и да је оправдано и разумно признати титулару повређеног права или интереса право на надокнаду штете. Оправданост и разумност примене ове санкције процениће судија имајући у виду облик одговорности за повреду, природу штете, блискост штете и радње која ју је изазвала, оправдана очекивања оштећеног и, напослетку, јавни интерес. Укључивање јавног интереса у процену даје судији простора за закључак да се повреда може боље отклонити другим правним средствима и по другим правним правилима, уместо одштетних. У таквом случају, судијски је закључак да нема правно значајне штете (legally relevant damage), већ повреде другим нормама санкционисане или чак губитка који оштећени мора сам поднети. 